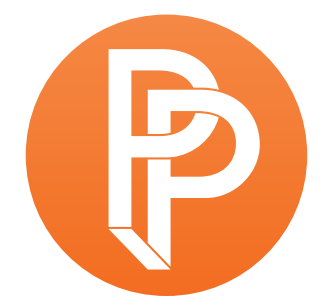

PERFORMANCE

PHILOSOPHY

\title{
NIETZSCHE: AN IMMANENTIST? ${ }^{1}$
}

\section{ANDREAS URS SOMMER UNIVERSITY OF FREIBURG}

\author{
Transcribed in the original spoken German by Eva-Maria Aigner \\ Translation from German to English: Gratia Stryker-Härtel
}

Good morning, my dear ladies and gentlemen!

This morning's lecture will be a rather unusual performance. First, you will be able to enjoy a very old-fashioned kind of lecture, as I won't present any PowerPoint slides; and second, I will be presenting my paper primarily in German. Since this could be problematic for some, I will provide English abstracts summarizing the main points. I will be using the German for two reasons: It seems rather unusual to present an author and his philosophy in a foreign language and not the language in which he lived when the greater part of the audience shares the author's language. In Paris, nobody would deliver a lecture on Descartes or Sartre in English or Swahili to a mainly French audience; and in London, no one would ever present a paper on John Stuart Mill or Thomas Hobbes in German or Swahili. The main reason I am refraining from the use of English is not the quite snobbish pretention of protecting my own language. Rather, it is the fact that it is not possible for me to show you the nuances of Nietzsche's work in English; Nietzsche is a master of nuances. In the third portion of my paper, you will see that the English translations in our conference reader are terribly misleading in at least two cases; when we try to interpret Nietzsche, we should refer back to the original language, not only in reading him but also in presenting him-at least I, for one, feel obliged to do so. 
My paper consists of three chapters. The first chapter deals with the concept deals with Nietzsche's usage of the concept of "immanence;" I will be tracing his usage of this term. My second point is a more general one. I would like to focus on the question as to whether it is possible for Nietzsche to have a strong concept of immanence, particularly when we recall that Nietzsche clearly formulates his strong opposition to all ideas of transcendence. Might any immanence at all be retained here? The third chapter contains an in-depth examination of two sections of Beyond Good and Evil, Sections 3 and 6 . I think we are able to note some important aspects in these passages as we seek to understand whether Nietzsche has any kind of idea or concept of immanence.

With that, I arrive at my first point and the passages in Nietzsche's work that deal with "immanence" and "immanent." We must recall within this context that our usage of the term "immanence" at this conference-namely, as a term standing in dichotomous opposition to "transcendence"-is a relatively recent development within the history of philosophy. For Baruch de Spinoza, the author at the root of all our considerations, the term representing the opposite of "immanent" is not "transcendent" but rather "transient" (vorübergehend). Immanence and transience are contrasted; the substance immanent within these modes is simply not a transient substance. This usage of the term, which traces back to scholasticism, underwent a fundamental change at the end of the $18^{\text {th }}$ century in Kant's Critique of Pure Reason, where we first encounter the distinction-so familiar to us today-between immanent and transcendent. My wish is not to explore this in detail here but simply to present it as preceding background information: background information that is vitally important in examining any contemporaneous usage of words conceptually related to "immanence." When we look for passages in which Nietzsche addresses immanence, we find there are not many. Passages addressing transcendence, on the other hand, are much more numerous, but these are not what I wish to discuss. These, incidentally, stem largely from the Nachlass-if I recall correctly, there are only two pertinent passages in the works published by Nietzsche himself (Human, All Too Human, Part I, Section 96 and The Gay Science, Section 292). Nietzsche's Nachlass tends to be overrated; there is an old reflex within the field of Nietzsche research to act on an assumption that the most important parts are hidden within it, that the truly representative work is ultimately to be found there. The truth is, however, that the Nachlass serves first and foremost as a workshop and laboratory, not as a finished product. Nietzsche was very much in a position to distinguish the one from the other, a capability that stands in unfortunate contrast to those interpreting his works today when they fish out some seemingly fitting passage from the Nachlass and make it the pivotal point of their Nietzschean analysis. This does not mean that one should completely exclude the Nachlass; it is absolutely helpful to draw upon the reservoir of the Nachlass to help us understand Nietzsche's terminological decisions in his works.

Chronologically, the first passage addressing immanence to be found in the Nachlass dates to 1869 and addresses the religion of the Greeks, preparing the conceptual approach to the Greek religion taken in The Birth of Tragedy. There, we read the following: "Religion for life: absolutely immanent: religion of beauty as one of blossoming, not of lack. Neither pessimists nor optimists" (NF-1869, $\left.3[42]^{2}\right)$._-Again: "Religion for life: absolutely immanent." You see the fundamental opposition we 
must bear in mind, my dear listeners; namely, a fundamental opposition to Christianity, which shifts the focal point of life to the afterlife. This is, if you will, a very early partisan stance in favor of immanence; however, strictly speaking, it is not yet programmatic but rather a kind of religious studies fieldwork findings-and, incidentally, something that Nietzsche could have found in a number of places as he read the literature.

Proceeding further through the relevant passages in the Nachlass, we see that what then interests him is the question as to whether there are immanent laws and standard measures (Gesetze und $\mathrm{Maße}$ ) in the universe-that is to say, not imposed from the outside, as by gods, for example, but resulting from the intrinsic substantive logic of the course taken by the world. These are notions Nietzsche particularly finds in Presocratic philosophy. He takes up the considerations of Empedocles and Heraclitus that appear to postulate immanent laws (Gesetzmäßigkeiten) in the universe. In Section 5 of Philosophy in the Tragic Age of the Greeks, an essay not published by Nietzsche himself, he speaks of the "inviolable laws and standards that are immanent in the struggle [of the qualities] (dem Kampfe immanenten Gesetzen und Maaßen)“ (Nietzsche 1998b, 55), while also tailoring his words to Heraclitus as follows in Section 7: "The very same immanent lawful order and justice reveals itself in the highest and in the wrongest man" (Nietzsche 1998b, 63-64).

Now, one might think that Nietzsche is fascinated by this concept of an immanent order, an immanent form of justice. However, given further examination, particularly of Nietzsche's Nachlass - the works themselves, as previously stated, provide us with very little; he does not seem to have considered the term "immanence" fit for use there-we find passages there such as the following: "All sorts of such possible visions of 'immanent justice,' 'sacred order,' counterbalancing 'transcendent justice' go around in everyone's heads today-they contribute to the chaos of the modern soul" (NF-1884, 26 [279] ${ }^{3}$ ). One could theorize from the previously cited statements of early Nietzsche that he is pitting immanence against transcendence-that he wants to weigh immanent justice as against transcendent justice in the balances. However, this is clearly thrown into question in view of these later passages. If we take a look at those passages from the Nachlass (there are more, e.g., NF-1885, 34[5], NF-1885, 40[62] and Nietzsche 2003, 124 (NF-1886, 6[9])), they prove quite critical in nature. They imply that speaking of immanent justice in drawing on the Presocratics would as much fall under the suspicion of metaphysics, or just as equally appear to be an untenable projection, as would the alternative, namely, a supernatural sacred order, transcendent justice. Hence, it is not the case that Nietzsche, as proven by the Nachlass, asserts usage of the terminology of immanence vs. transcendence as a legitimate option in the 1880s. Rather, the impression arises that ideas of immanence-which are harmonistic, ontologically euphemistic concepts-must fall to criticism in equal measure as must those asserting there is a transcendent order imposed upon us. Only with difficulty would one be able to work with the concept of immanence itself whenever attempting to clearly portray Nietzsche's oppositional position within the history of his ideas. The only passage that is truly relevant when it comes to usage of the word "immanence" as a term within Nietzsche's works (and I am no longer speaking of the Nachlass but instead of his published works) is The Gay Science, Section 292; and there he speaks "of justice and immanent retribution" that some would place "at the head of [their] morality" and talk about "from morning to night," in short representing a "popularity and clamor of the streets (Popularität und ein 
Geschrei der Gassen)" (Nietzsche 1974, 234). Hence, the idea of immanent retribution such that things are brought to rights on the basis of an innate order somehow present and rooted within the universe at large appears to be a laughable metaphysical assumption to the first-person narrator of The Gay Science, Section 292. This is along the very same lines as what we find in the Nachlass dating to the 1880s in terms of the concept of immanence. At this point, we must recall that the usage of the term "immanence" to mean the opposite of "transcendence" was thrown into question in the second half of the $19^{\text {th }}$ century by many authors well known to Nietzsche who were critical of religion (for example Ludwig Feuerbach, Max Stirner und Eduard von Hartmann). These authors attempted to establish a philosophy of immanence in order to fully dispose of any correlation with transcendence. Nietzsche quite clearly finds this approach strange, even holding it to be a "clamor of the masses;" he sees it as a sign of "the chaos of the modern soul" that one would adopt something like this or even hopelessly jumble together things such as immanent and transcendent justice-and considering it apparent that the modern individual has the tendency to bring things into utter confusion whenever that helps satisfy the need for solace and deeper significance.

Not much, apparently, can be concluded regarding Nietzsche's use of concept of immanence. This, however, does not necessarily speak against an immanence-philosophical interpretation of Nietzsche not centered on the term. One can of course readily argue that it seems Nietzsche might not have liked the term "immanence" and actually lodged fundamental reservations about it. This, however, does not necessarily mean that, on principle, he would then have to utterly reject a philosophy of immanence, such as the one we know from Gilles Deleuze; perhaps Nietzsche simply preferred to use other terms.

A short abstract of this first part: I argue that in Nietzsche's posthumous fragments, he does not cast the concept of immanence in a very friendly light. Obviously, at the beginning of his thinking, he saw that a kind of immanent religion was possible, particularly in ancient Greece, and that the Presocratic philosophers had obviously believed in a kind of immanent order within the universe. On the other hand, Nietzsche is very critical in the 1880 s about the possibility of re-establishing an immanent order today; hence, the concept of "immanence" and the usage of this term seems unsuitable for contemporary thought and thought that could also be relevant for the future, since the term, according to Nietzsche, is still overloaded with metaphysical implications. Thus, freely making use of the term "immanence" and its underlying conceptual framework does not provide a means of escape when it comes to transcendence, for example, or the old notion of God. Something else has to be found. It might certainly be possible that one could translate criticism of the term "immanence" in Nietzsche into a philosophy of immanence-with the help of Deleuze, for instance. Perhaps Nietzsche is only critical of the term "immanence" but not of the issue behind the term. 
This brings me to my second point. The marginal nature we have ascertained regarding the term "immanence" is not surprising; after all, should one wish to create a strong term for immanence, one also needs an opposing concept. And the opposite concept that philosophy has been offering us since Kant-one which perpetually dominated, particularly in the Hegelian tradition but also in the anti-Hegelian tradition-is, as I already made clear at the very beginning, the concept of transcendence. This mode of thinking is no longer viable for Nietzsche, however, since one always asks about the external when it comes to immanence-and it is no longer viable because Nietzsche, clearly, is actually attempting to conceptualize plural unity. One might thus say he is offering alternatives to the concept of immanence, which appears contaminated to him. The primary alternative is the concept of life; the ancillary alternative, the concept of the "will to power." This is not about teachings or the last definitions bequeathed us by Nietzsche. It seems much more appropriate to me to characterize these considerations of Nietzsche as an intellectual experiment. Nietzsche is not acting as teacher of the eternal recurrence; rather, he is occasionally allowing for the appearance of a Persian prophet functioning as the teacher of such a teaching. The same thing-or something analogue-also applies to the will to power and the Übermensch. One might say Nietzsche avoids the concept of immanence and words surrounding the concept of immanence because the concept cries out for an "other," an opposing option, which Nietzsche does not wish to concede. Indeed, one could very well argue that Nietzsche is an eminent immanence philosopher when he allows his prophet figure, Zarathustra, to preach that one should "remain true to the Earth." This sounds like the watchword of a philosophy of immanence-a watchword tailor-fit to a radical focus on the substance of this world rather than the next. As is well known, Nietzsche accuses those still caught up in the notion that there must be a God beyond the bounds of this world, in the hereafter, of shifting the weight to unduly favor a way of life negating the here and now, this world, and life itself (with "way of life," Lebensform, itself almost calling for quotation marks). Nietzsche's denunciatory gesture leads to the conclusion that those who allow themselves to be defined by ascetic ideals (as addressed by Arno Böhler's article in this publication) are those who do not wish to take seriously that radical immanence (to use the term after all, although Nietzsche, as already stated, would never employ the term "immanence" here); these are the ones who are actually abnegating life. Nietzsche as the defender of an immanence thus understood also has a certain plausibility. He is, after all, the unceasing critic of shifting the weight of being to another place and time.

There are also passages in Nietzsche that seem to disclose him as a religious thinker; I wish to point out one of these passages, since I neglected to discuss this spot in more detail in the treatise I once wrote on Twilight of the Idols (cf. Sommer 2012) and would like to make up for that now. The focus of my examination is on a passage in Twilight of the Idols, or How to Philosophize with a Hammer, from 1888, a passage in which the first-person narrator claims to be the "last disciple of the philosopher Dionysus" (Nietzsche 1998a, 81), a declaration that appears to have the character of an emphatic avowal. This passage is seized upon in Ecce homo, the autogenealogy Nietzsche wrote in the last creative months of his life; in the work, we see variations and extensions of that same declaration: "I am a disciple of the philosopher Dionysus; I should prefer to be even a satyr to being a saint" (Nietzsche 1989, 217). This certainly catches our attention, and we ask: Is this an affirmative avowal to a kind of anti-God? 
The first confusing thing about this is that information about this Dionysus figure is quite definitely provided in other works, such as in Section 295 of Beyond Good and Evil published two years prior. There, Dionysus is initially introduced not as a philosopher but rather as god-rather than being a normal god, however, he is a "tempter god," (Nietzsche 2002, 176) a god of the greatest possible ambiguity; this Dionysus appears to be a very strange god indeed, not just the affirmation of life in incarnate form as one might imagine. Apparently, a "tempter god" is one that throws fundamental certainties into question-the first being all certainties that one commonly holds as able to be associated with gods.

A second strange aspect of this avowal to be the last disciple of the philosopher Dionysus is the way it holds to Dionysus as philosopher. Since when is Dionysus a philosopher? Is he not supposedly a god? When would one ever profess avowal to the philosopher Jesus of Nazareth or the philosopher Gautama Buddha? It is rather unlikely_so what is the "philosopher" doing here? In Twilight of the Idols (Nietzsche 1998a, 52-53), we also have the fragments of a dialogue between Dionysus and Ariadne-Ariadne, who was deserted by Theseus and caught by Dionysus on Naxos-very peculiar fragments that, according to Nietzsche, reveal the philosopher Dionysus. But who is the philosopher Dionysus in contrast to the god Dionysus? Can gods philosophize?

There is yet a third thing that should catch our attention when interpreting this passage: "I am the last disciple of Dionysus." There are two possible interpretations: The speaker is the last disciple because none come after him, since the possibilities of professing avowal have been exhausted; or, in a second possibility, we recall to mind that, according to Christian terminology, the last disciple is the betrayer, Judas Iscariot - the one who triggered the dispatch of the Roman pursuers to seize Jesus, who accepted payment of thirty silver coins for it and hung himself afterwards. Is the last disciple of the philosopher Dionysus thus the one who betrays Dionysus? This interpretation has a certain draw in view of Zarathustra's announcement to his disciples, "Only when you have all denied me will I return to you" (Nietzsche 2005, 68). In no way does Zarathustra wish to have faithful disciples.

And now I leave that as is. I simply wanted to demonstrate to you how extraordinarily difficult it is to pin any specific avowals to Nietzsche. If we take these apparent avowals and look at them more closely, what opens up before us is a yawning chasm; we are not sure what he actually wants to say to us here, what it is he is avowing and what kind of avowal he requires from his readers. Should we now become the disciples of the last disciple-Judas' disciples? I do not know, and I simply wish to invite you not to derail in hasty conclusions when interpreting Nietzsche.

Abstract of the second part: It is at the very least possible to construe Nietzsche as a philosopher of immanence, because he is so clearly critical regarding the possibility of transferring the heavy weight of existence into another sphere, a transcendent sphere. This Schwergewichtsverlagerung is the main issue Nietzsche addresses in his criticism of Christianity and of asceticism. One could thus translate Nietzsche's philosophy of life into the concept of immanence. However, examining the texts more closely, we see that there is not at all a clear and definitive version of Nietzsche's 
philosophy of immanence, philosophy of life or philosophy of the will to power. These concepts, life and will to power-so prominent in Nietzsche-are more intellectual experiments than they are doctrines. In essence, Nietzsche is not a teacher of doctrines; rather, he is a great experimenter. And this is also the case with Dionysus. Nietzsche seems to admire and pray to the god Dionysus, but we see that Nietzsche construes himself as the last disciple of the philosopher Dionysus; and as aforementioned, the sentence "I am the last disciple of the philosopher Dionysus" seems much less clear than superficial, because Nietzsche here is clearly not interested in the god Dionysus but rather in the philosopher Dionysus. The narrator ego speaking in Twilight of the Idols is, as the last disciple, obviously a kind of Judas Iscariot-the traitor, the one who has betrayed Jesus. The narrating ego confessing his attachment/belonging to the philosopher Dionysus may thus also be a kind of traitor. Upon closer examination, the sentence quoted above is at the least not as clear as it seems to be.

With that, I come to my third and last point and will quickly read Section 6 from Beyond Good and Evil: "In contrast, there is absolutely nothing impersonal about the philosopher; and in particular his morals bear decided and decisive witness to who he is-which means, in what order of rank the innermost drives (Triebe) of his nature stand with respect to each other" (Nietzsche 2002, 9). Beyond Good and Evil was published in 1886.

If we dig around a little bit, we find that this passage has a very interesting preceding history-very interesting history reaching back to Nietzsche's encounter with Lou von Salomé in Tautenburg in 1882. Nietzsche and Salomé were enjoying an intellectual summer retreat, one which contemporaneous records unfortunately do not document from von Salomé's perspective, save for her Tautenburg chronicle of letters to Paul Rée (Andreas-Salomé 1970, 181-190). Nietzsche, on the other hand, does provide us with a record-a text from this summer of ' 82 that he wrote for Lou von Salomé. (You see how I hesitate to just designate her "Lou." I find it strange when Nietzsche scholars talk about "Lou" in referring to Lou von Salomé but, when speaking of Nietzsche's friends Franz Overbeck or Erwin Rohde, never just say "Franz" or "Erwin." One should be consistent and either accustom oneself to the former-Fritz's philosophy, Franz's theological criticism and Lou's novel-or speak of Nietzsche's philosophy, Overbeck's theological criticism and Salomé's or Andreas-Salomé's novel).

In a letter from Nietzsche to Salomé, probably from September 16, 1882, we read, "My dear Lou, Your thought as to a reduction of philosophical systems to personnel files (Personalakten) of their creators is truly a thought from a 'kindred brain'-l myself, due to the very same reasoning, told stories of the old philosophies in Basle and liked to say to my listeners: 'This system is rebutted and dead-but the person behind it is incontrovertible; the person can in no way be made deadPlato, for example'"' (BVN-1882, 3054). We see from this that Nietzsche had received a letter from Salomé (it is exceedingly regrettable that the letter remains unknown to us) in which she suggests that we understand philosophies-or, to be more exact, philosophical systems-as the Personalakten of their creator, that is to say, as a specific expression of their author's personality. 
According to such an interpretation, systems would be not something the philosophers simply put to paper as a kind of instrument of truth, divested of any personal involvement. This would imply a fundamental difference between the philosophy of Heraclitus and the philosophy of Hegel, the philosophy of Kant and the philosophy of Plato. Hence, Lou von Salomé drafts here a concept for the history of philosophy that I roughly dub the "personnel files method"-a "reduction of philosophical systems to the personnel files of their creators," as Nietzsche formulated it. As I said, we do not know what Lou von Salomé's original formulation or the concept was. What we do have, however, is her book on Nietzsche from 1894-which, by the way, is one of the best books we have on Nietzsche. In it, she begins by reprinting a facsimile of this letter from Nietzsche and establishes her own method of approaching Nietzsche in a kind of attempt, as it were, to present Nietzsche's intellectual Personalakten. She takes the method she drafted in 1882 with Nietzsche (in conversation, however) and, twelve years later-with Nietzsche long since sunken into lunacyshe uses it as an aid to pen her own book on Nietzsche.

Upon further investigation of the matter in Nietzsche's Nachlass, we are able to observe a shift-a shift toward "confessions of their creator;" you hear, of course, the echoes of Augustine in the background. Philosophy is no longer a set of "personnel files" - that sounds too technical and bureaucratic-but rather personal confessions, and, according to notes from Nietzsche's Nachlass dating to 1883 , what stands behind them is not a drive for knowledge (Erkenntnistrieb) but rather "drives (Triebe) that serve knowledge (Erkenntnis) like a tool" (M III 4, 90f. bzw. KSA 14, 348f5), as it is formulated. Suddenly, we see use of the term Trieb ("drive") a term that played no role as of the letter to Lou von Salomé in 1882, where talk merely centered on Personalakten. I leave this varied assortment of terms to your good judgment, and I also leave it to you to revert to the lecture on Greek philosophy Nietzsche held in Basle and mentioned in his letter to Lou von Salomé. As a matter of fact, Nietzsche had already pursued a similar line of thought during his time in Basle between 1869 and 1879, extending his considerations in the Nachlass from 1883 to include musicians rather than merely philosophers; the creations of musicians, he states, are subjected to the very same logic of "personal confessions" (Selbstbekenntnis) and "drive" (Trieb) as those of the philosophers. "The philosopher is just a kind of opportunity (Gelegenheit) and enabling conduit (Ermöglichung) giving verbal expression to the drive (Trieb)" (NF 1883, 7[62]). ${ }^{6}$

You see the shift, a shift all the way from that of personal confessions and personnel files to the life of drives (Triebleben), that unconscious Triebleben. This change finds its basis in particular lectures by Nietzsche (the details of which I will also leave to you). Nietzsche often stylizes himself as an author who is thoroughly independent of and detached from contemporaneous discourse; he likes to act as if he stands in complete isolation. He does not and cannot, of course; in truth, he is keenly intent on absorbing and integrating every possible bit of contemporaneous debate. We would be suffering from an optical illusion if we thought Nietzsche is the way he likes to stylize himself-thinker of thinkers at the apex of a mountain, untouched by everything save any truly great ones that may have previously existed. You can just visualize Nietzsche, far up there on his mountaintop, as it were, waving down - all the way back to Spinoza and Plato. The fact is, however, that he, too, moved about in the endless sway of analytical confrontation with the contemporaneous body of literature; and, because we typically no longer have any general 
familiarity with that literature, we really do suffer from such an optical illusion. Nietzsche is a highly reactive thinker; he always seizes on the stimuli and ideas of his day, his reactions depending on what books he currently has under his pillow and in hand. However, as stated, I now leave to you the details regarding the Triebleben and the literature on the Triebe.

It is interesting to note at this juncture the changes we see to the concept of the history of philosophy. As stated earlier, in 1874, in the Third Untimely Meditation on Schopenhauer as Educator, Section 8, "The only critique of a philosophy that is possible and that proves something, namely trying to see whether one can live in accordance with it, has never been taught at universities: all that has ever been taught is a critique of words by means of other words" (Nietzsche 1997, 187). This is a thoroughly classical criticism of philosophy that Nietzsche could have also found in the works of Schopenhauer or Emerson, for example. "Life" is our term of reference here; however, even though it sounds as if it could be analogue to everything we have heard about the Triebe, it does not really work in analogue. What is interesting is that Triebe play no role in this early concept of philosophy. Moreover, taking a closer look reveals that the term "life" is also employed differently. He was not able to establish these Trieb characteristics in such a way as they were later able to be developed against the backdrop of the natural sciences treatises of the 80s. Section 6 of Beyond Good and Evil no longer focuses on propagating a philosophy that governs life. That was still the exposition in Schopenhauer as Educator from 1874, according to which we need a philosophy to govern life. In Beyond Good and Evil from 1886, however, the inverse is the case; life determines philosophy via the Triebe. In other words, we seem to have the same governing termnamely, "life"-but with a clear inversion of the way the one term is related to the other. Now, life expresses its essence in philosophy, among other things. Philosophy is no longer required to negotiate life; rather, life always overcomes in the framework of philosophy. And the kind or form of life (Lebensform) we have leads to different forms of philosophy.

The Erkenntnistrieb is clearly nothing to be understood as an end in itself; the Erkenntnistrieb is an urge that serves knowledge (Erkenntnis) as a tool, according to Section 6 of Beyond Good and Evil. Scholars, it states, are perhaps those that have an Erkenntnistrieb because they are not really moved by passion. "Conversely, there is absolutely nothing impersonal about the philosopher; and his ethics, in particular, give decided and decisive witness as to who he is" (JGB-6). In 19th-century discourse, the impersonal was often the very embodiment of morality. According to this perspective, people should not be personally involved in their moral dealings; Kant makes it clear that there should be no personal involvement or partisanship for the sake of the personal. Nietzsche holds this in ethicis for a highly problematic perspectivation. Already Human, All Too Human, Part I, Section 95 from 1878 demonstrates the guiding principle for this. Section 6 of Beyond Good and Evil is based upon it. For Nietzsche, it is an illusion that one could just shut off the personal, particularly, and in the broadest sense, when it comes to morality; it is also an illusion, however, in view of aesthetics. In one passage of the letters of Gustave Flaubert to George Sand, Nietzsche wrote, "Je crois que le grand art est scientifique et impersonnel" (Flaubert 1884, 41). Flaubert, thus, believes that the greatest art is scientific and impersonal-a stance standing polar opposite to Nietzsche's own understanding of art and philosophy. It is his attempt, so to speak, to hold his ground against the scientism of his time. 
With that, I come to the last passage in the text. It deals with Beyond Good and Evil, Section 3.

As I mentioned at the beginning, I have some difficulties in that the nuances are improperly expressed in the English Nietzsche discussion and particularly in the Nietzsche translations. From my point of view, the translation offered in the conference reader ${ }^{7}$ is in many respects, to put it politely, rather misleading. To simply begin at the beginning: In the German text, you have a contrast drawn between fingers and eyes ("Nachdem ich lange genug den Philosophen zwischen die Zeilen und auf die Finger gesehn habe" (JGB-3)). Those fingers, however, suddenly disappear in the English text: "I have kept a close eye on the philosophers and read between their lines for long enough to say myself [...]" (Nietzsche 2002, 6-7)—Where are the fingers? Then, continuing: "Man muss hier umlernen." The English text renders umlernen as "re-examination" (Nietzsche 2002, 7 bzw. JGB-3). "Relearn," "trans-learn" or something of the like would offer us a more adequate translation; "re-examination" only means that you, well, look again, while umlernen means that you have changed your mind. Or take the very last sentence of the English translation: "But this assumes that it is not man who is the 'measure of things'..." (Nietzsche 2002, 7) The German text does not have this idea of consequence; it does not follow from what has been said before. Gesetzt nämlich is not at all an indication that we must induce a consequence from what precedes but is rather an elliptical form of speaking. This elliptical form of speaking has totally disappeared in the English translation. One should perhaps translate it with "Given that" or "Let us assume that;" but then we would also have a complete sentence whereas, in the German original, we do not have a grammatically complete sentence. And the gerade-"even"-has also disappeared in the English text. Hence, this translation of Beyond Good and Evil should really be reworked to provide a more adequate sense of the meaning of the text.

All that to say, translations of Nietzsche are exceedingly difficult, and I believe that in many cases, it would be more advisable to provide the text with a more literal, line-for-line translation than an interpretive one, as is regular practice. It is also confusing in German, of course, for one not only to read between the lines but also to look at the fingers. In undertaking a serious translation, however, one must attempt to render those nuances as well-precisely because the text should be just as confusing for the reader in another language as it is for the reader in German.

"I have kept a close eye on the philosophers and read between their lines for long enough to say to myself: the greatest part of conscious thought" (Nietzsche 2002, 6). It appears thoroughly selfevident to us that this is representative of Nietzsche's focus; after all, he was always talking about instincts. It is not quite that simple, however. Admittedly, we encounter the term "instinct" already early on in Nietzsche's oeuvre. His intention in using it there is denunciatory-against Euripides, for example. Euripides, namely, that Greek tragic poet, is served up the accusation of betraying the instinct, the instinctive. Nietzsche states in 1872 that the Greeks, apparently, had something like a harmoniousness of the instinctive; and Euripides, together with Socrates, was the one to destructively plow over the totality of it. 
We see this term, "instinct," already in early Nietzsche. One could think it is all somehow one and the same; but it is not. Nietzsche incorporates the natural sciences in a gradual augmentation of the term "instinct," which he initially adopted from the field of cultural journalism of his day. An important source in terms of this incorporation of the natural sciences is Georg Heinrich Schneider's Der menschliche Wille vom Standpunkte der neueren Entwicklungstheorien from 1882. As you can already see from the title, this work is about evolutionary biology, one of those disciplines that Nietzsche incorporates in his thinking in the 1880's for the sake of arming his philosophy with inclusion of the natural sciences. Schneider's book is found in Nietzsche's library, and in it is a passage reading, "[i]nstinctive action [...] in every respect [builds] the basis for expressions of the will (Willensäusserungen), strictly speaking. [...] Instinct is the psychological striving for the preservation of the species without a consciousness of the purpose of this striving." (Schneider 1882, 109) ${ }^{8}$ According to this, instincts are unconscious; they serve the preservation of the species, according to the Darwinian conceptualization as represented by Schneider. Nietzsche does not simply accept this Darwinian conceptualization but rather adapts it to fit into his own thinking; he proves highly critical in regard to Darwin-but that is another topic altogether (cp. Sommer 2010). What is important at this juncture is that he, along with Darwin, conceives of the human as historical, as a being that has undergone an evolutionary-historical process of becoming-as a being that has become what it is over the course of a developmental history. There is no doubt that he diverges greatly from Darwin and Darwinians in the details; but the basic intention, that of declaring that the human being is not simple but rather a being that has evolved-a biologically evolved beingis, as seen after Darwin, an irreducible assumption for Nietzsche. A second author Nietzsche uses to justify the instinctive anew is Otto Liebmann, an important philosopher who, while Neo-Kantian, is also at home in the natural sciences. Nietzsche underlined numerous passages in his essay entitled Ueber den Instinct, published in 1880, making quite a few glosses and positive remarks in its margins. Nietzsche is in no way squeamish in the remarks he often annotates in his books, with judgments like "Ass!" and "Idiot!" far from seldom. In this work by Liebmann, however, we see an emphatic "Yes!" scrawled in the margins of passages such as the following (with Nietzsche's underlining):

\footnotetext{
On the other hand, the functions of the human spirit most worthy of appreciationmoral tact and artistic genius - are essentially one with the animal instinct, differing from it only slightly, seemingly belonging to the same genus as it, that is, the selfsame apparent outpouring of a higher inspiration. Instinct, tact and genius converge in their unconsidered feeling of, desire for and enaction of the right and appropriate; they exist in the ability to immediately hit the nail on the head without deliberation, without experience or practice, without reflection or premeditation, without unsteadiness, doubt or weighing things back and forth. (Liebmann 1880, $410)^{9}$
}

In sum, the fragments of a theory of instinct in Nietzsche are bound up with contemporaneous discussions and combine biological relativity with historical and societal relativity. Instinct is not something simply imposed upon us by a biological scheme; rather, instinct is something that emerges, that is created. It is not, however, something we ourselves create but rather something 
we inherit-from our parents and grandparents, as well as from the protozoa at the very inception of our phylogeny.

But this assumes that it is not man who is the "measure of things..." (Nietzsche 2002, 7) ("Gesetzt nämlich, dass nicht gerade der Mensch das 'Maass der Dinge' ist..." (JGB-3)). As previously stated, I hold that Judith Norman's translation of this last sentence in Beyond Good and Evil, Section 3, leads us astray in that it suggests a consequence deduced from that which precedes it, something which is not the case. Historical-philosophical reference is clearly being made here to Protagoras of Abdera's homo-mensura statement, according to which "man [is] the measure of all things, of the things they are, and of the things they are not." What is remarkable here is the way it opens up to something indeterminate, while previously, in the same section, Section 3 of Beyond Good and Evil, criticizes the fallacious belief of philosophies "that the determinate is worth more than the indeterminate" (Nietzsche 2002, 7) ("[...] dass das Bestimmte mehr werth sei als das Unbestimmte" (JGB-3)). The end of the sentence does not provide any defined alternative, as one would expectsuch as the defined declaration that the standard of all things is not the human but rather instinct, or the animal in humans, or the protozoan in humans or any other such thing. No, Nietzsche does not provide this. What we have here is an assertion, a hypothetical statement positing that man is not the measure of all things, but the text refrains from providing information as to what, in his place, is the measure of all things. No alternative is offered. We could speculate that Nietzsche is possibly asserting that rationality is not the measure of all things, as the philosophers always liked to believe-that there is no abstract man who is the measure of all things. Also, in Protagoras' original text, äv $\theta \rho \omega \pi$ ro , "man," is not preceded by the definite article, hence it would actually be "mankind" that is "the measure of all things"-the question is whether "man" is being used in a generalized or specific way. In weighing all the possibilities, it seems to me that the path open to us is that of the philosophical labor of thinking forged ahead by the reader him- or herself. The text does not give us any answers as to what the measure of all things now is. Just as a side note, what we have here is an intertextual reference to Human, All Too Human, Section 2, which deals with the philosophical conceptualization of ' 'man' as an aeterna veritas, as something that remains constant in the midst of all flux, as a sure measure of things" (Nietzsche 1996, 12). This section likewise expounds on the problems of envisioning the human as the established standard measure and recommends in its stead a historical philosophization-philosophizing that understands man as a historical being, a being that is becoming.

Very brief abstract: In dealing with Sections 3 and 6 of Beyond Good and Evil, I attempted to show that what seems so clear on the surface is not at all clear when we take a closer look at the text. We must consider the background, the context into and from which Nietzsche wrote. Thus, in our interpretation of Nietzsche, we must avoid propagandizing the big terms, believing that we can pin him down just with those big terms. We must read and interpret Nietzsche carefully because we are always involved in intellectual experiments; Nietzsche performs intellectual experiments not only with his texts but also with his readers-with us as his readers. 
In closing, you see, ladies and gentlemen, that-to summarize-it is far from clear what Nietzsche considers to be the measure of all things. Apparently, it is not immanent laws (which brings me back to the very beginning again) that somehow exist out there, with which we just simply have to comply, as perhaps the Presocratists and many philosophers after them believed. There are clearly very individual and historically/biologically/societally evolved standards, or measures (Maßstäbe), that are laws; but only individual laws, depending on how and into what we develop. It is not the case that life expresses itself in one standard way; rather, life quite clearly means the greatest possible extent of plurality. As for the question I pose in the title presaging all these considerations as to whether Nietzsche is an immanentist, you can, of course, see my skeptical reservations. In no way would I wish to try to pin Nietzsche down as an "-ist" or to an "-ism." Nietzsche is not "the philosopher of the will" or "the life philosopher" or "the amor-fati philosopher;" he is all sorts of things, encompassing all of it but also not all of it at the same time. Hence, he is as much not an immanentist as he isn't, if you will allow me the paradoxical formulation.

Perhaps he holds no attachment to the privileged places in which immanence makes its appearance. Perhaps die Fülle des Daseins ("abundance of existence"), Eigentlichkeit ("authenticity"), are granted everywhere, always. Perhaps we have no particular places where we can, for example, experience Eigentlichkeit-and many other places where we cannot do so. Why assume an Eigentlichkeit is hidden somewhere instead of finding the Eigentlichkeit realized here and now and in every moment? I gladly concede that this final conclusion is one I myself would draw and one to which I would hope Nietzsche would respond by formulating the greatest possible reservations and objections. Thank you.

Notes

${ }^{1}$ All original German Nietzsche citations in this article are taken from the Digitalen kritischen Gesamtausgabe by Giorgio Colli and Mazzino Montinari, published by Paolo D'lorio, at http://nietzschesource.org/\#eKGWB.

2 “Die Religion für das Leben: ganz immanent: Religion der Schönheit als der Blüthe, nicht des Mangels. Weder Pessimisten noch Optimisten” (NF-1869, 3[42]). [Passage translated from German by Gratia Stryker-Härtel.]

3 “Alle möglichen solchen Vorstellungen über 'immanente Gerechtigkeit', Heilsordnung', ausgleichende 'transcendente Gerechtigkeit' gehen jetzt in jedem Kopfe herum—sie bilden das Chaos der modernen Seele mit.” [Passage translated from German by Gratia Stryker-Härtel.]

4 " Meine liebe Lou, Ihr Gedanke einer Reduktion der philosophischen Systeme auf Personal-Actenihrer Urheber ist recht ein Gedanke aus dem ,Geschwistergehirn': ich selber habe in Basel in diesem Sinne Geschichte der alten Philosophie erzählt und sagte gern meinen Zuhörern: dies System ist widerlegt und todt-aber die Person dahinter ist unwiderlegbar, die Person ist gar nicht todt zu machen'—zum Beispiel Plato." [Passage translated from German by Gratia Stryker-Härtel.]

5 "[...] Triebe, welche sich der Erkenntnis wie eines Werkzeugs bedienen." [Passage translated from German by Gratia-Stryker-Härtel.]

6 "Der Philosoph ist nur eine Art Gelegenheit und Ermöglichung dafür, daß der Trieb einmal zum Reden kommt." [Passage translated from German by Gratia Stryker-Härtel.] 
7 The translation in the conference reader refers to: Nietzsche (2002).

8 "Das instinctive Handeln bildet [...] in jeder Hinsicht die Grundlage zu den Willensäusserungen im engeren Sinn. [...] Instinct ist das psychische Streben nach Arterhaltung ohne Bewusstsein des Zweckes von diesem Streben." Passage translated from German by Gratia Stryker-Härtel.

9 "Andererseits sind die bewunderungswürdigsten Functionen des menschlichen Geistes, sittlicher Tact und künstlerisches Genie, mit dem Instinct der Thiere wesentlich einerlei, nur graduell von ihm verschieden mit ihm offenbar unter dasselbe Genus gehörig, nämlich, wie er anscheinend Ausflüsse einer höheren Inspiration. Instinct, Tact, Geniekommen darin überein, daß sie unüberlegt das Richtige und Angemessene fühlen, wollen und thun; sie bestehen in der Fähigkeit, ohne Vorbedacht, ohne Erfahrung und Einübung, ohne Reflexion und Prämeditation, ohne Schwanken, Zweifeln und Hin- und Hererwägen sofort den Nagel auf den Kopf zu treffen." Passage translated from German by Gratia Stryker-Härtel.

\section{Works Cited}

Andreas-Salomé, Lou. 1970. "Tagebuch für Paul Rée." In Die Dokumente ihrer Begegnung, based on the erstwhile collaboration with Karl Schlechta and Erhart Thierbach, published by Ernst Pfeiffer, 181-190. Frankfurt/Main: Insel Verlag.

Flaubert, Gustave. 1884. Lettres à George Sand. Précédées d'une étude par Guy de Maupassant. Paris: C. Charpentier.

Liebmann, Otto. 1880. Zur Analysis der Wirklichkeit. Eine Erörterung der Grundprobleme der Philosophie. $2^{\text {nd }}$ edition. Straßburg: Trübner.

Nietzsche, Friedrich. 1974. The Gay Science. Translated by Walter Kaufmann. New York: Vintage.

___. 1989. Ecce homo. Translated by Walter Kaufmann. New York: Vintage.

___. 1996. Human, All too Human. Translated by R. J. Hollingdale. Cambridge: Cambridge University Press.

_-_. 1997. Untimely Meditations. Translated by R. J. Hollingdale. Cambridge: Cambridge University Press.

-_- 1998a. Twilight of the Idols or How to Philosophize with a Hammer. Translated by Duncan Large. Oxford/New York: Oxford University Press.

_-_. 1998b. Philosophy in the Tragic Age of the Greeks. Translated by Marianne Cowen. Washington: Regnery.

_-_. 1999. Sämtliche Werke. Kritische Studienausgabe in 15 Einzelbänden. Edited by Giorgio Colli und Mazzino Montinari. 3. Auflage. München/Berlin/New York: DTV Walter de Gruyter [=KSA].

-_- 2002. Beyond Good and Evil. Prelude to a Philosophy of the Future. Edited by Rolf-Peter Horstmann. Translated by Judith Norman. Cambridge: Cambridge University Press.

_- - 2003. Writings from the Late Notebooks. Translated by Kate Sturge. Cambridge: Cambridge University Press.

_-_. 2005. Thus spoke Zarathustra. Translated by Graham Parkes. Oxford/New York: Oxford University Press.

Schneider, Georg Heinrich. 1882. Der menschliche Wille vom Standpunkte der neueren Entwicklungstheorien (des „Darwinismus"). Berlin: Ferd. Dümmlers Verlagsbuchhandlung.

Sommer, Andreas Urs. 2010. "Nietzsche mit und gegen Darwin in den Schriften von 1888." Nietzscheforschung. Jahrbuch der Nietzsche-Gesellschaft 17: 31-44.

- - 2 2012. Nietzsche-Kommentar: Der Fall Wagner und Götzen-Dämmerung. Historischer und kritischer Kommentar zu Friedrich Nietzsches Werken. Bd. 6/1. Berlin/Boston: Walter de Gruyter. 
Andreas Urs Sommer is Professor of Philosophy with an emphasis in cultural philosophy and holds an academic professorship in cooperation with the Heidelberg Academy of Sciences and Humanities.

Born in 1972, Sommer studied philosophy, the history of the church and dogma as well as German literary studies in Basle, Göttingen and Freiburg im Breisgau, becoming licentiate in 1995. He was promoted to the University of Basel in 1998 and was visiting research fellow at Princeton University in 1998-1999. Sommer served as assistant lecturer at the Institute of Philosophy at the University of Greifswald between 2000 and 2006 and as a visiting fellow at the School for Advanced Study at the University of London in 2001; he completed his postdoctoral studies in 2004 at the University of Greifswald. In 2007, he served as interim professor at the University of Mannheim, undertaking scholarly commentary on the works of Nietzsche between 2008 and 2014 as director of the Friedrich Nietzsche Foundation and serving as guest professor at the Karlsruhe University of Arts and Design between 2013 and 2014. Sommer has been serving as director of the "Nietzsche Commentary" research center at the Heidelberg Academy of Sciences and Humanities since 2014 and as Professor of Philosophy with an emphasis in cultural philosophy at the University of Freiburg since 2011, holding an adjunct professorship between 2011-2016 before accepting a full professorship in 2016.

\section{(c) 2017 Andreas Urs Sommer}

cC) (i) (2) Except where otherwise noted, this work is licensed under a Creative Commons Attribution-

cC) NonCommercial-ShareAlike 4.0 International License. 